\title{
Experimental study on steam gasification of coal using molten blast furnace slag as heat carrier for producing
} hydrogen-enriched syngas

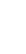
Wenjun Duan, Qingbo Yu*, Tianwei Wu, Fan Yang, Qin Qin

School of Materials and Metallurgy, Northeastern University, No 11, Lane 3, Wenhua Road, He Ping District, Shenyang 110819, Liaoning, People’s Republic of China.

\section{*Corresponding author information:}

Telephone/Fax: +86-024-83672216.

E-mail addresses: duanwenjn@163.com (W. J. Duan) 


\section{Abstract}

The new method for producing hydrogen-enriched syngas (HRG) by steam gasification of coal using molten blast furnace slag (BFS) as heat carrier was established. In order to achieve the HRG production, a gasification system using this method was proposed and constructed. The carbon gasification efficiency (CE), hydrogen yield $\left(\mathrm{YH}_{2}\right)$ and cold gasification efficiency (CGE) in the molten slag reactor were measured, and the effects of temperature, S/C (steam to coal) ratio and coal type on the reaction performance were accessed. The results indicated that the preferred temperature was $1350^{\circ} \mathrm{C}$, which ensured the miscibility of coal-steam-slag, the diffusion of reactant in molten BFS as well as recovering waste heat. The optimal S/C ratio was 1.5 2.0 for producing HRG. Under these conditions, the hydrogen fraction was higher than $63 \%$ and the gas yield reached to $1.89 \mathrm{Nm}^{3} / \mathrm{kg}$. The CE and CGE were higher than $96 \%$ and $102 \%$, respectively. The $\mathrm{YH}_{2}$ also reached to 1.20 $\mathrm{Nm}^{3} / \mathrm{kg}$. Meanwhile, different types of coal were successfully gasified in molten BFS reactor for producing HRG. The proposed method enhanced the gasification efficiency of different types of coal, recovered the BFS waste heat effectively, and had important guidance for industrial manufacture.

\section{Keywords:}

Hydrogen-enriched syngas; Molten blast furnace slag; Waste heat; Steam gasification; Heat carrier 


\section{Introduction}

Hydrogen was a very versatile environmental energy carrier and the development of cheap and clean hydrogen generation technology had been the most hot research topic $[1,2]$. The method of steam gasification with fossil fuels or renewable to produce hydrogen was widely accepted [3, 4]. However, for steam gasification process, some key reactions were intensely endothermic reactions and demanded a large amount of energy [5-7]. In general, the energy was provided by fossil fuel or syngas combustion. Meanwhile, a certain amount of $\mathrm{CO}_{2}$ was produced in steam gasification process and not friendly for the environment $[8,9]$. Therefore, it was essential to find a reasonable energy supply to achieve the environmental and economic benefits in steam gasification process for producing hydrogen.

As we all know, iron and steel industry was an energy-intensive industry, which accounted for approximating 5\% of the total energy consumption with a waste heat recovery rate of only $17 \%$ [10-12]. BFS was exhausted at extremely high temperature (about $1500-1600^{\circ} \mathrm{C}$ ), and the energy carried was about $1700 \mathrm{MJ} / \mathrm{t}_{\text {slag. }}$. For example, in 2013, the crude steel production reached up to 822 million tons in China, which meant that the waste heat of hot slag was equivalent to 14.8 million tons standard coal [13]. Therefore, establishing an integrated system of recovering BFS waste heat to provide the energy needed for the steam gasification process was necessary. In the theoretical analysis, Ishida [14] established the enthalpy-exergy diagram to analyze the BFS waste heat recovery. Akiyama et al [15] described a feasibility study of recovering BFS heat using nine chemical reactions by enthalpy-exergy diagram method. By this 
method, thermodynamic analysis of BFS waste heat recovery system integrated with coal gasification was conducted by Duan et al [16]. The results showed that the exergy efficiency and recycling efficiency of the established system were $52.6 \%$ and $75.4 \%$, respectively. The exergy loss of the integrated system was only $620.0 \mathrm{MJ} / \mathrm{t}_{\text {slag. }}$. Meanwhile, the thermodynamic analysis of steam gasification using BFS as heat carrier and recycling its waste heat to produce HRG were investigated by Duan et al $[12,17]$. The results suggested that the preferred condition for HRG from Datong coal was achieved at $775^{\circ} \mathrm{C}$, atmospheric pressure and $\mathrm{S} / \mathrm{C}$ ratio of $2.0-3.0$. In experimental studies, Luo et al [18] established a continuous moving-bed biomass gasification reactor to evaluate the feasibility of recovering BFS particles waste heat and producing $\mathrm{HRG}$ at $1000^{\circ} \mathrm{C}$. Zhao [19] investigated the possibility of producing the combustible gas from municipal solid waste using BFS waste heat. In his study, the effects of temperature, gasifying agent and BFS particles on the gas production were studied at $600-900^{\circ} \mathrm{C}$. Sun et al [20] also investigated the characteristics of biomass gasification and syngas release behavior using hot slag at the low temperature $\left(200-450^{\circ} \mathrm{C}\right)$. The syngas $\left(0.149 \mathrm{~L} \mathrm{CO}, 0.036 \mathrm{~L} \mathrm{H}_{2}\right.$ and $\left.0.069 \mathrm{~L} \mathrm{CH}_{4}\right)$ could be produced by per gram of wheat straw when the biomass was mixed with slag. Obviously, the current methods of producing hydrogen by steam gasification using BFS waste heat were entirely feasible. But these methods were only limited to using slag particles at relatively low temperature. However, for BFS waste heat, the high-grade waste heat mainly concentrated in molten slag at $1250^{\circ} \mathrm{C} \sim 1600^{\circ} \mathrm{C}$. The process of hydrogen production by steam gasification using molten BFS as heat 
carrier was never referred to and lack of comprehensive study. Therefore, it was necessary to investigate the steam gasification process using molten BFS as heat carrier, which would be more benefit for hydrogen production and recovering high-grade waste heat.

In the present study, the approach for steam gasification of coal in molten BFS to produce HRG was proposed and implemented. The effects of temperature, S/C ratio and coal type on steam gasification reaction were investigated, so as to obtain the optimal operation parameters and guide the industrial production.

\section{Materials and methods}

\subsection{Feedstock}

Five types of coal (Datong (DT) coal, Fuxin (FX) coal, Fushun (FS) coal, Shennan (SN) coal and Dezhou (DZ) coal) were obtained from various big coal mines in Northern China for gasification experiments to produce HRG. Their compositions and properties were shown in Table 1. The ultimate analysis of the sample was conducted using a CHNS/O Analyzer, Perkin Elmer PE 2400 series II. The proximate analysis of the sample was conducted using an automatic coal proximate analyzer. During preparing coal samples, the first step crushing coal pieces with a hammer and crusher for the appropriate size. Then these crushed particles were segregated into about 75 $\mu \mathrm{m}$ using a series of sieve shakers.

BFS from an iron and steel company was used in experiments as heat carrier with chemical compositions of 41.21 mass $\% \mathrm{CaO}, 34.38$ mass $\% \mathrm{SiO}_{2}, 11.05$ mass $\% \mathrm{Al}_{2} \mathrm{O}_{3}$, 8.22 mass $\% \mathrm{MgO}, 2.78$ mass $\% \mathrm{Fe}_{2} \mathrm{O}_{3}, 0.35$ mass $\% \mathrm{TiO}_{2}$ and some minor constituents 
101 of sulfur, manganese and phosphor oxides. Its chemical compositions were analyzed 102 by X-ray fluoroscopy (XRF, SE-Explore, Bruker). In the experiment, the pulverized 103 coal was conveyed by carrier gas and the reactor should be replenished with shielding 104 gas before the experiment. The carrier gas and shielding gas used in experiments were $105 \mathrm{~N}_{2}$ with $99.99 \%$ purity.

106 Table 1 The proximate and elemental analysis of the coal

\begin{tabular}{|c|c|c|c|c|c|}
\hline Coal & DT & $\mathrm{FX}$ & FS & $\mathrm{SN}$ & $\mathrm{DZ}$ \\
\hline \multicolumn{6}{|c|}{ Proximate analysis (wt\%) } \\
\hline Moisture, wt $\%$ & 9.05 & 3.13 & 1.83 & 2.30 & 4.96 \\
\hline Volatile matter, wt $\%$ & 38.38 & 32.78 & 28.72 & 26.38 & 4.82 \\
\hline Fixed carbon, wt $\%$ & 38.42 & 34.79 & 20.81 & 22.85 & 19.11 \\
\hline Ash, wt $\%$ & 14.15 & 29.30 & 48.64 & 48.47 & 71.11 \\
\hline \multicolumn{6}{|c|}{ Ultimate analysis (wt\%) } \\
\hline Carbon & 64.53 & 52.27 & 39.05 & 42.59 & 21.57 \\
\hline Hydrogen & 3.746 & 4.204 & 3.489 & 3.379 & 0.710 \\
\hline Nitrogen & 0.956 & 1.09 & 1.13 & 0.74 & 0.19 \\
\hline Sulfur & 0.561 & 1.210 & 0.619 & 0.967 & 0.457 \\
\hline Oxygen & 7.007 & 8.796 & 5.242 & 1.554 & 1.003 \\
\hline
\end{tabular}

\subsection{Experimental system}

108 The experiment system of steam gasification of coal using molten BFS as heat 109 carrier for producing HRG was established, as shown in Fig. 1. The system was 110 composed of seven parts: feeding system, primary reactor system, temperature 


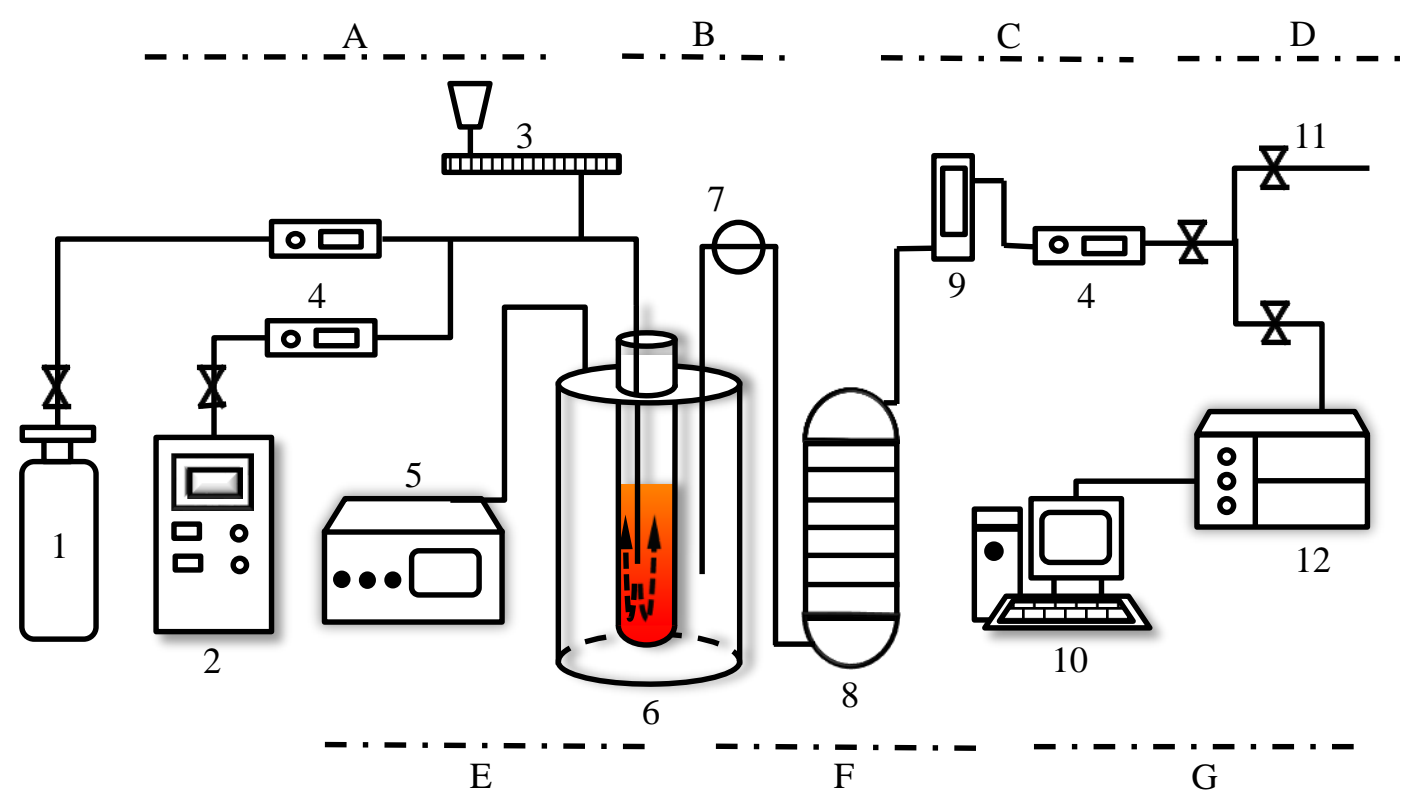

1. $\mathrm{N}_{2}$ Cylinder; 2. Steam Generator; 3. Screw Feeder; 4. Gasometer; 5. Control Cabinet;

6. Electric Furnace; 7. Temperature Measuring; 8. Heat Exchanger; 9. Drier; 10.

Computer; 11. Exhaust; 12. Gas Analyzer.

A. Feeding System; B. Temperature Measurement System; C. Flow Measurement

System; D. Off-gas Treatment System; E. Primary Reactor System; F. Gas Purification

System; G. Gas Composition Analysis System.

Fig. 1 The schematic diagram of the experimental apparatus

Fig. 2. The high purity corundum with high corrosion resistance was adopted as the reactor so as to perform the reaction for a long time. The reactor, which was externally heated in an electric furnace (SG1-15-16), had a height of $100 \mathrm{~cm}$ and a volume of $196 \mathrm{~cm}^{3}$. Meanwhile, the feeding system was also a key part to ensure the successful experiment. The powder feeder (TWLP 15) was adopted in the feeding 
122

123

system, and the rate was controlled in the rage of $2.0 \mathrm{~g} / \mathrm{min} \sim 25 \mathrm{~g} / \mathrm{min}$. The bulk density of the pulverized coal in the powder feeder was about $0.74 \mathrm{~g} / \mathrm{cm}^{3}$. At last, the portable gas analyzer (Gasboard-3100P) was used to ensure the accuracy of the experimental results.

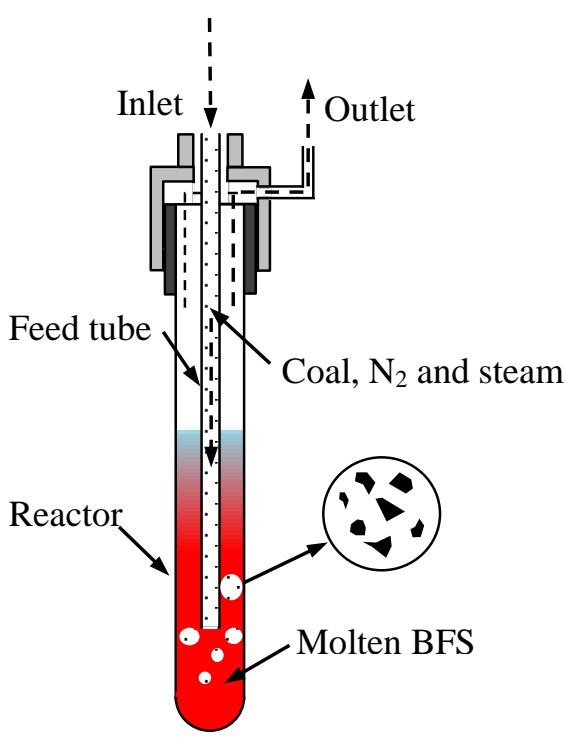

Fig. 2 The schematic diagram of the primary reactor

\subsection{Experimental procedure}

In a typical test, the suitable height of the molten BFS was about $300 \mathrm{~mm}$ for the gasification reaction [21]. Therefore, about $1.8 \mathrm{~kg}$ BFS particles sample was crushed and ground to about $2 \mathrm{~mm}$ and then put into the reactor. The loaded reactor was placed in the electric furnace and heated to the target temperature, and then kept it about 2 hours so as to the temperature remain stable and evenly distribute. The rated power, rated voltage and rated temperature of the electric furnace were $15 \mathrm{KW}, 380 \mathrm{~V}$ and $1600^{\circ} \mathrm{C}$, respectively. The reactor was insulated with glass wool material to maintain the temperature of gasification reaction in molten BFS. Furthermore, there was a temperature controller with a thermocouple (type K) placed into the reactor to 


$$
\mathrm{LHV}_{\text {syngas }}\left(\mathrm{MJ} / \mathrm{Nm}^{3}\right)=\left(108.0 \mathrm{H}_{2}+126.4 \mathrm{CO}+358.2 \mathrm{CH}_{4}\right) \times 10^{-3}
$$

control and record the temperature. When steam stream and the target temperature were stable after about half an hour, the powder feeder worked and the pulverized coal was carried into the reactor by $\mathrm{N}_{2}$. At this time, the coal gasification reaction with steam was carried out in molten BFS and produced the HRG. The composition of syngas was recorded by gas analyzer, and the powder feeder was closed after the gas composition being stable for 30 minutes. The gasification reaction finished when the content of hydrogen reached to zero, and the next experiment could be carried out by repeating the above steps. The operating conditions of the gasification experiment were shown in Table 2.

\subsection{Method of data processing}

The carbon gasification efficiency (CE) was calculated by [22]:

$\mathrm{CE}(\%)=\frac{12\left(\mathrm{CO}+\mathrm{CO}_{2}+\mathrm{CH}_{4}\right) \mathrm{Y}_{\mathrm{G}, \mathrm{daf}}}{22.4 \mathrm{C}_{\mathrm{daf}}} \times 100 \%$

where, $\mathrm{Y}_{\mathrm{G} \text {,daf }},\left(\mathrm{CO}+\mathrm{CO}_{2}+\mathrm{CH}_{4}\right)$ and $\mathrm{C}_{\mathrm{daf}}$ were the gas yield, volumetric fraction of syngas compositions and mass of carbon in coal on dry and ash free basis, respectively.

The hydrogen yield $\left(\mathrm{YH}_{2}\right)$ was calculated by [22]:

$\mathrm{YH}_{2}(\mathrm{~mol} / \mathrm{kg})=\frac{n_{\mathrm{H}_{2}}}{m_{\text {coal }}}$ 
presented in the literature $[23,24]$ :

160

$$
\begin{aligned}
\mathrm{HHV}_{\text {coal }}(\mathrm{MJ} / \mathrm{kg})= & 0.33(\text { Volatiles matter })-0.11(\text { Moisture }) \\
& +0.35(\text { Fixed carbon })-0.03(\text { Ash })
\end{aligned}
$$

161 The lower heating value of the coal could be estimated by [25]:

$162 \mathrm{LHV}_{\text {coal }}(\mathrm{MJ} / \mathrm{kg})=\mathrm{HHV}_{\text {coal }}-9 m_{\mathrm{H}}\left(h_{f g}\right)$

163 where, $m_{\mathrm{H}}$ was the mass fraction of hydrogen in the coal, and $h_{f g}$ was the enthalpy of 164 vaporization of water.

165 Based on the Eq. (3) and Eq. (5), the cold gasification efficiency (CGE) could be 166 obtained:

$167 \mathrm{CGE}(\%)=\frac{\mathrm{LHV}_{\text {syngas }}\left(\mathrm{MJ} / \mathrm{Nm}^{3}\right) \times \mathrm{V}_{\text {syngas }}\left(\mathrm{Nm}^{3} / \mathrm{kg}\right)}{\mathrm{LHV}_{\text {coal }}(\mathrm{MJ} / \mathrm{kg})}$

\begin{tabular}{|c|c|c|c|c|}
\hline Particle size $(\mu \mathrm{m})$ & Coal Type & Temperature $\left({ }^{\circ} \mathrm{C}\right)$ & $\mathrm{S} / \mathrm{C}$ ratio & Bed height $(\mathrm{mm})$ \\
\hline \multirow{7}{*}{75} & & 1200 & & \multirow{7}{*}{300} \\
\hline & DT coal & 1250 & $1: 1$ & \\
\hline & FX coal & 1300 & $1.5: 1$ & \\
\hline & FS coal & 1350 & $2: 1$ & \\
\hline & SN coal & 1400 & $2.5: 1$ & \\
\hline & \multirow[t]{2}{*}{ DZ coal } & 1450 & \multirow[t]{2}{*}{$3: 1$} & \\
\hline & & 1500 & & \\
\hline
\end{tabular}

Table 2 The operating conditions in the gasification system

\section{Results and discussions}

171 Since there were no references regarding the production of HRG by steam 
172

173

gasification of coal in molten BFS, the characteristics of steam gasification in molten BFS were firstly studied. The steam gasification in molten BFS was successfully carried out and produced a large amount of HRG. Meanwhile, the effects of temperature, S/C ratio and coal type on gasification reaction were discussed, respectively. The optimal operation parameters were obtained for guiding industrial production.

\subsection{Effect of the gasification temperature}

The temperature could significantly influence the gasification performance by promoting or inhibiting the reaction rate and changing the chemical reaction equilibrium. The effect of the temperature $\left(1200^{\circ} \mathrm{C} \sim 1500^{\circ} \mathrm{C}\right)$ on the gasification performance of FS coal was studied with S/C ratio of 2.0 and reactor bed height of $300 \mathrm{~mm}$. As seen in Table 3, with temperature increasing, the carbon residue decreased from $6.15 \mathrm{~mol} / \mathrm{kg}$ to $0.37 \mathrm{~mol} / \mathrm{kg}$ and the gas yield increased from 1.73 $\mathrm{Nm}^{3} / \mathrm{kg}$ to $1.91 \mathrm{Nm}^{3} / \mathrm{kg}$. It was because that higher temperature provided more favorable conditions for thermal cracking and steam reforming of carbon, thus the carbon residue dramatically decreased. Meanwhile, the cracking of volatile matter accelerated at high temperature, which was another reason for changing the gasification performance [2].

The fraction distribution of production syngas related with the reaction temperature was shown in Fig. 3. It could be seen from the picture, the fraction of $\mathrm{H}_{2}$ and $\mathrm{CO}_{2}$ decreased steadily with the temperature increasing, but the change of $\mathrm{CO}$ fraction was contrary to them. The fraction of $\mathrm{CH}_{4}$ was infausted with the increasing of 
194 195 196

197 root of the change was the reverse water gas shift reaction $\left(\mathrm{CO}+\mathrm{H}_{2} \mathrm{O} \leftrightharpoons \mathrm{CO}_{2}+\mathrm{H}_{2}\right)$ was 198 significantly stimulated in the molten BFS when the temperature and carbon 199 conversion arrived to some level, compared with the primary water gas reaction $\left(\mathrm{C}_{\mathrm{S}}+\right.$ $200 \mathrm{H}_{2} \mathrm{O} \leftrightharpoons \mathrm{CO}+\mathrm{H}_{2}$ ). In the whole temperature range, the $\mathrm{H}_{2}$ fraction was higher than $20162 \%$, and the combustion gases were higher than $70 \%$. Therefore, the results indicated 202 that producing HRG by the steam gasification of coal in molten BFS was feasible.

\begin{tabular}{ccccc}
\hline $\begin{array}{c}\text { Temperature } \\
\left({ }^{\circ} \mathrm{C}\right)\end{array}$ & Carbon residue & Gas Yield & H Yield & Gas LHV \\
\hline 1200 & 6.15 & 1.73 & 1.14 & 9.73 \\
1250 & 4.23 & 1.81 & 1.18 & 9.94 \\
1300 & 2.66 & 1.86 & 1.19 & 10.11 \\
1350 & 1.25 & 1.89 & 1.20 & 10.24 \\
1400 & 0.73 & 1.90 & 1.20 & 10.34 \\
1450 & 0.42 & 1.91 & 1.19 & 10.42 \\
1500 & 0.37 & 1.91 & 1.19 & 10.49 \\
\hline
\end{tabular}




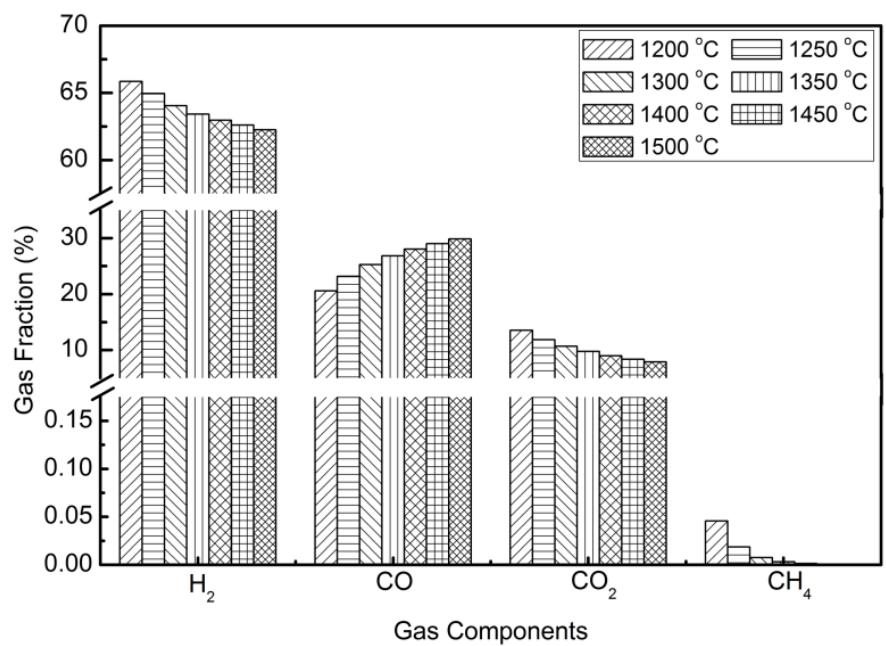

Fig. 3 The effect of temperature on syngas fraction distribution of FS coal gasification $(\mathrm{S} / \mathrm{C}$ ratio $=$

The characteristics of $\mathrm{CE}, \mathrm{CGE}$ and $\mathrm{YH}_{2}$ with different temperatures were shown in

Fig. 4. As the temperature increased from $1200^{\circ} \mathrm{C}$ to $1500^{\circ} \mathrm{C}, \mathrm{CE}$ and $\mathrm{CGE}$ increased

firstly and then remained relatively stable, especially the CE increased from $81.10 \%$

to $98.88 \%$, while the $\mathrm{YH}_{2}$ increased from $50.90 \mathrm{~mol} / \mathrm{kg}$ to $53.52 \mathrm{~mol} / \mathrm{kg}$ and then decreased to $53.06 \mathrm{~mol} / \mathrm{kg}$. The steam gasification benefited from increasing temperature, but the temperature's contribution slowed down when the temperature was higher than $1350^{\circ} \mathrm{C}$. It was because that increasing the reaction temperature could decrease the viscosity of molten BFS, enhance the miscibility of coal-steam-slag as well as the diffusion of reactant in molten BFS [26, 27]. When the viscosity reduced to a certain value, there was no remarkable influence on the miscibility and diffusion 218 in the gasification process because the viscosity of the molten BFS basically kept 219 steady. As can be seen from Fig. 5, with the BFS temperature increasing, the viscosity of the slag decreased sharply at the melting temperature and then decreased moderately. The viscosity of molten BFS decreased to be lower than 2.50 $\mathrm{Pa} \cdot \mathrm{s}$ when 
223 [28-30], the viscosity of slag should be usually maintained to be lower than $2.50 \mathrm{~Pa} \cdot \mathrm{s}$

224 so as to guarantee the coal gasification reaction process proceeding smoothly and the

225 subsequent processing of the slag (granulating-rotary cup atomizer). Meanwhile, the

226 lower gasification temperature was, the more waste heat of BFS was recovered.

227 Therefore, taking various elements into consideration, such as gasification efficiency,

$228 \mathrm{H}_{2}$ yield production and waste heat recovery, et al, the optimal operation temperature

229 of steam gasification in molten BFS was controlled around $1350^{\circ} \mathrm{C}$.

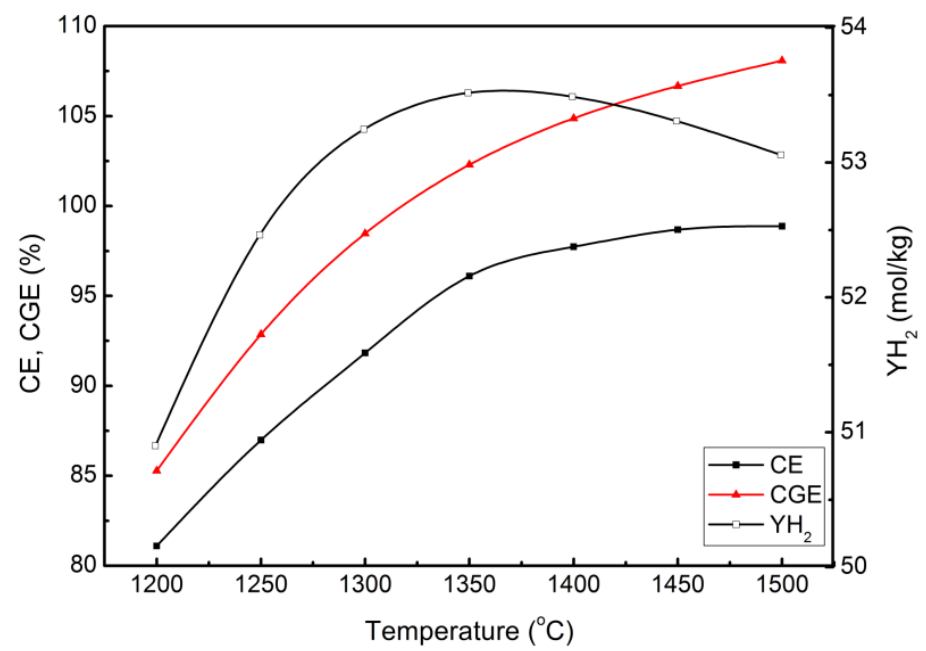

Fig. 4 The characteristic of $\mathrm{CE}, \mathrm{CGE}$ and $\mathrm{YH}_{2}$ with different temperatures $(\mathrm{S} / \mathrm{C}$ ratio $=2.0)$

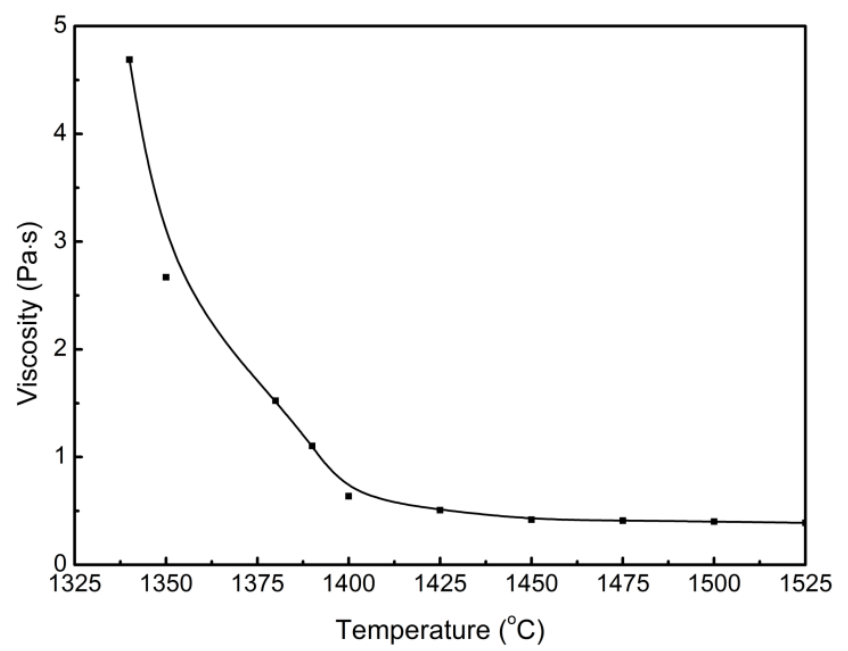

233 Fig. 5 The effect of temperature on the viscosity of BFS in the FS coal gasification system 


\begin{tabular}{ccccc}
\hline S/C ratio & Carbon residue & Gas Yield & $\mathrm{H}_{2}$ Yield & Gas LHV \\
& $(\mathrm{mol} / \mathrm{kg})$ & $\left(\mathrm{Nm}^{3} / \mathrm{kg}\right)$ & $\left(\mathrm{Nm}^{3} / \mathrm{kg}\right)$ & $\left(\mathrm{MJ} / \mathrm{Nm}^{3}\right)$ \\
\hline $1: 1$ & 4.93 & 1.48 & 0.95 & 10.98 \\
$1.5: 1$ & 2.49 & 1.76 & 1.10 & 10.61 \\
$2: 1$ & 1.25 & 1.89 & 1.20 & 10.24 \\
$2.5: 1$ & 0.73 & 1.97 & 1.27 & 9.94 \\
$3: 1$ & 0.46 & 2.03 & 1.31 & 9.70 \\
\hline
\end{tabular}

Fig. 6 showed the variation of syngas fractions with different S/C ratios. The 

coal gasification reaction?

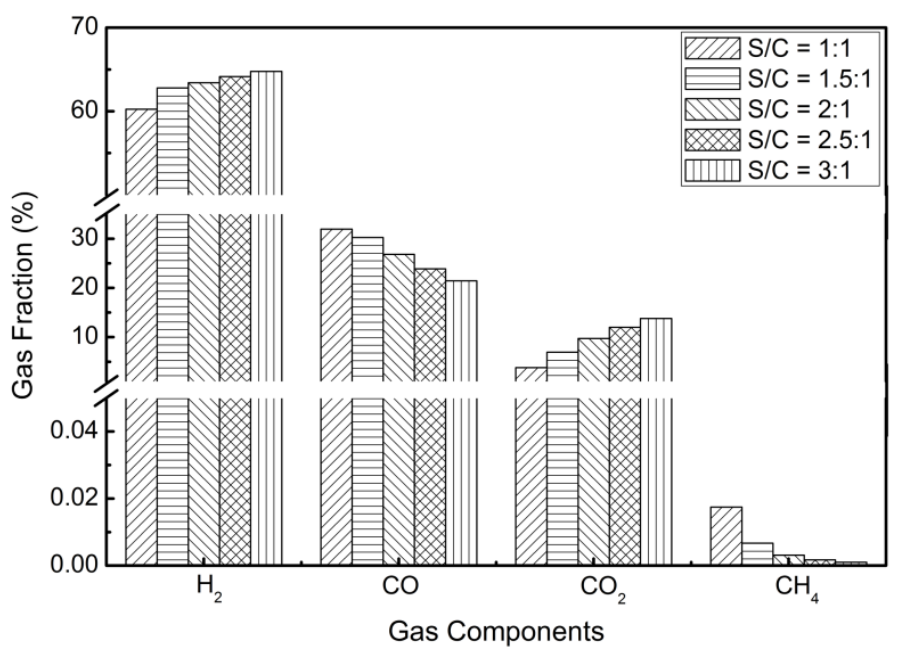

254

Fig. 6 The effect of S/C ratio on syngas fraction distribution of FS coal gasification (Temperature

$$
\left.=1350^{\circ} \mathrm{C}\right)
$$

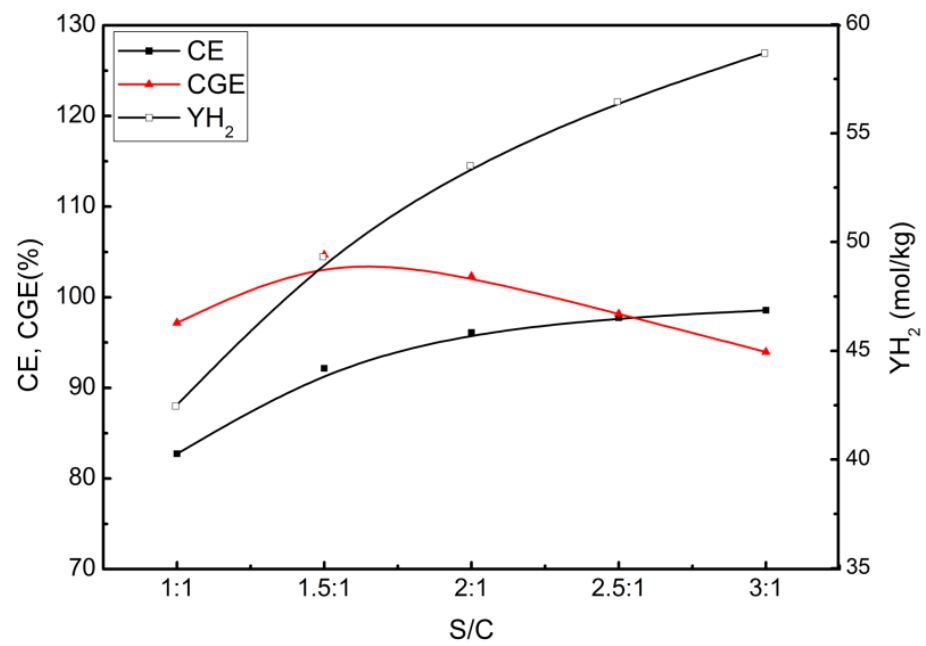

Fig. 7 The characteristic of $\mathrm{CE}, \mathrm{CGE}$ and $\mathrm{YH}_{2}$ with different $\mathrm{S} / \mathrm{C}$ ratios $\left(\right.$ Temperature $\left.=1350^{\circ} \mathrm{C}\right)$

As can be seen from Fig. 7, for the CGE, firstly it rose to a peak with the S/C ratio around 1.5, and after that it began to monotonically decrease. It was pointed out that 
the change of CGE was mainly caused by the extra steam introduced more than the necessity for gasification [17]. Therefore, although increasing S/C ratio was favorable to produce $\mathrm{HRG}$, the optimal parameter of $\mathrm{S} / \mathrm{C}$ ratio was $1.5 \sim 2.0$ considering the energy consumption of the gasification system.

\subsection{Effect of the coal type on gasification reaction}

In general, the steam gasification of a coal species was affected by its properties such as volatile matter, ash and carbon content, et al. Table 5 showed the gasification performance of the five typical Northern China coals. As shown in Table 5, there was no significant difference on carbon residue for different types of coal, but the production of gas yield and $\mathrm{H}_{2}$ yield significantly decreased from DT coal to DZ coal in the process of steam gasification in molten BFS. Compared with the production syngas of DT coal, the significant reduction of gas yield and $\mathrm{H}_{2}$ yield were mainly due to the high content of ash in DZ coal. On analysis, for different types of coal, the steam gasification reaction could proceed smoothly and effectively with the molten BFS as heat carrier.

As shown in Fig. 8, syngas production with high $\mathrm{H}_{2}$ fraction and relatively lower $\mathrm{CO}$ and $\mathrm{CO}_{2}$ was obtained from the five coal samples. $\mathrm{CO}_{2}$ fraction was lower than $10 \%$ in these five samples, which indicated that the controlling temperature and $\mathrm{S} / \mathrm{C}$ ratio were applicable. The maximum $\mathrm{H}_{2}$ fraction (64.26\%) was obtained from $\mathrm{SN}$ coal, whereas the minimum of $\mathrm{H}_{2}$ fraction $(58.76 \%$ ) was obtained from DZ coal. These differences were mainly caused by the different chemical compositions of the coals, which were shown in Table 1. 


\begin{tabular}{ccccc}
\hline Coal Type & $\begin{array}{c}\text { Carbon residue } \\
(\mathrm{mol} / \mathrm{kg})\end{array}$ & Gas Yield & $\mathrm{H}_{2}$ Yield & Gas LHV \\
& 1.18 & 2.99 & 1.81 & 10.16 \\
$\mathrm{DT}$ & 1.05 & 2.50 & 1.55 & 10.18 \\
$\mathrm{FX}$ & 1.25 & 1.89 & 1.20 & 10.24 \\
$\mathrm{FS}$ & 1.24 & 1.94 & 1.24 & 10.25 \\
$\mathrm{SN}$ & 0.84 & 0.93 & 0.55 & 10.03 \\
$\mathrm{DZ}$ & & & & \\
\hline
\end{tabular}

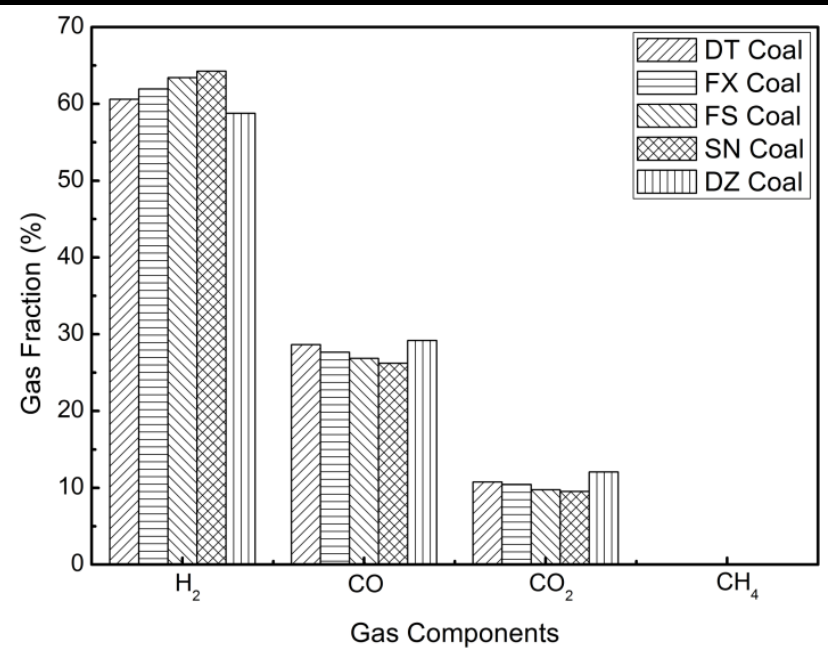

Fig. 8 The effect of coal type on syngas fraction distribution $\left(\right.$ Temperature $=1350^{\circ} \mathrm{C}$ and $\mathrm{S} / \mathrm{C}$ ratio

2919 . So, in the gasification, this method could be applied widely in various types of coal 292 to produce the HRG. 


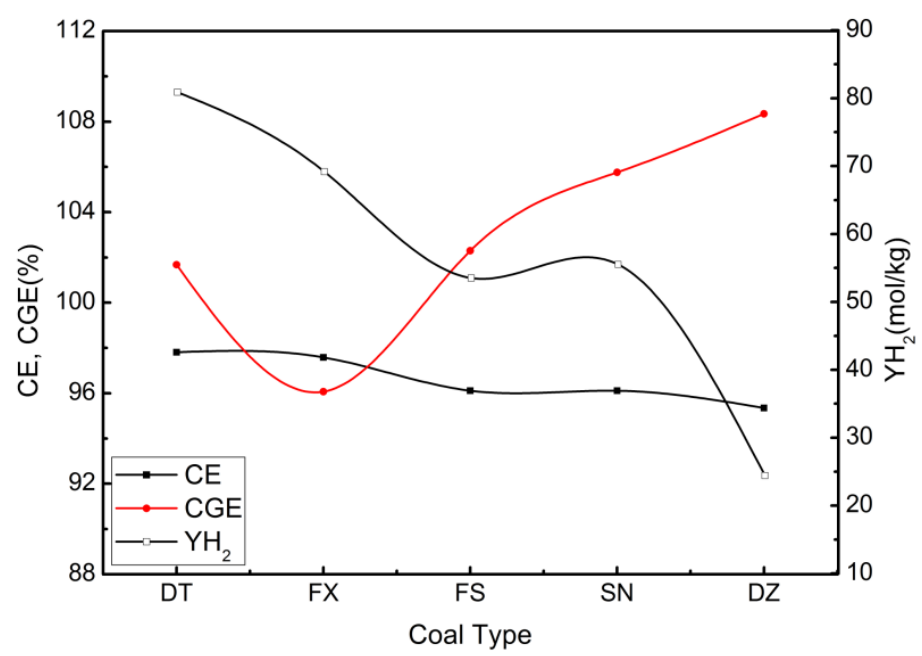

Fig. 9 The characteristic of $\mathrm{CE}, \mathrm{CGE}$ and $\mathrm{YH}_{2}$ with different types of coal $\left(\right.$ Temperature $=1350^{\circ} \mathrm{C}$,

and $\mathrm{S} / \mathrm{C}=2.0$ )

\section{Conclusions}

The system of producing HRG by steam gasification of coal using molten BFS as heat carrier was proposed. The effects of the gasifier temperature, S/C ratio and coal type on the gasification were investigated. Experimental results showed that the hydrogen yield, gas yield, and hydrogen fraction et al were strongly related with the temperature, S/C ratio. The preferred conditions for HRG from FS coal were achieved at $1350^{\circ} \mathrm{C}$ and $\mathrm{S} / \mathrm{C}$ ratio of $1.5 \sim 2.0$. Under these conditions, the hydrogen fraction was higher than $63 \%$ and the gas yield reached to $1.89 \mathrm{Nm}^{3} / \mathrm{kg}$. The CE and CGE were higher than $96 \%$ and $102 \%$, respectively. The $\mathrm{YH}_{2}$ also reached to $1.20 \mathrm{Nm}^{3} / \mathrm{kg}$. By this method, different types of coal were gasified effectively in molten BFS, which effectively solved the utilization of coal. using molten BFS as heat carrier. 


\section{Nomenclature}

$311 n_{\mathrm{H}_{2}}=$ the mole of the product hydrogen, mol;

$312 \quad m_{\text {coal }}=$ the mass of the coal, $\mathrm{kg}$;

$313 m_{\mathrm{H}}=$ the mass fraction of hydrogen in the coal, \%;

$314 h_{f g}=$ the enthalpy of vaporization of water, $\mathrm{MJ} / \mathrm{kg}$.

\section{Abbreviations}

$316 \quad \mathrm{BFS}=$ Blast furnace slag

$317 \quad \mathrm{HRG}=$ hydrogen-enriched syngas

$318 \quad$ DT coal $=$ Datong coal

$319 \quad$ FX coal $=$ Fuxin coal

$320 \quad$ FS coal $=$ Fushun coal

$321 \quad$ SN coal $=$ Shennan coal

$322 \quad$ DZ coal = Dezhou coal

$323 \quad \mathrm{CE}=$ Carbon gasification efficiency

$324 \quad \mathrm{YH}_{2}=$ Hydrogen yield

$325 \quad$ LHV = Lower heating value

$326 \quad \mathrm{HHV}=$ Higher heating value

$327 \quad$ CGE $=$ Cold gasification efficiency

\section{Acknowledgements}

329 This research was supposed by The National Natural Science Foundation of China 330 (51274066, 51304048), The National Science Foundation for Post-doctoral Scientists of China (2015M571322), The National Key Technologies R\&D Program of China 
332

333

(2013BAA03B03), The Fundamental Research Funds for the Central Universities

(N130402019).

\section{References}

[1]. Kang K, Azargonhar R, Dalai AK, Wang H. Systematic screening and modification of $\mathrm{Ni}$ based catalysts for hydrogen generation from supercritical water gasification of lignin. Chemical Engineering Journal 2015; 283: 1019-1032.

[2]. Wang RP, Huang QX, Lu P, Li WJ, Wang SK, Chi Y, Yan JH. Experimental study on air/steam gasification of leather scraps using U-type catalytic gasification for producing hydrogen-enriched syngas. International Journal of Hydrogen Energy 2015; 40: 8322-8329.

[3]. Xia A, Cheng J, Song WL, Su HB, Ding LK, Lin RC, Lu HX, Liu JZ, Zhou JH, Cen KF. Fermentative hydrogen production using algal biomass as feedstock. Renewable and Sustainable Energy Reviews 2015; 51: 209-230.

[4]. John RP, Anisha GS, Nampoothiri KM, Pandey A. Micro and macroalgal biomass: a renewable source for bioethanol. Bioresource Technology 2011; 102: 186-193.

[5]. Luo SY, Xiao B, Hu ZQ, Liu SM, Guo XJ, He MY. Hydrogen-rich gas from catalytic steam gasification of biomass in a fixed bed reactor: influence of temperature and steam on gasification performance. International Journal of Hydrogen Energy 2009; 34: 2191-2194.

[6]. Tao J, Lu Q, Dong CQ, Du XZ, Dahlquist E. Effects of electric current upon catalytic steam reforming of biomass gasification tar model compounds to syngas. Energy Conversion and Management 2015; 100: 56-63. 
354

355

[7]. Karnjanakom S, Guan GQ, Asep B, Du X, Hao XG, Samart C, Abudula A. Catalytic steam reforming of tar derived from steam gasification of sunflower stalk over ethylene glycol assisting prepared Ni/MCM-41. Energy Conversion and Management 2015; 98: 359-368.

[8]. Mohammad S. Masnadi, John R. Grace, Xiaotao T. Bi, Naoko Ellis, C. Jim Lim, James W. Butler. Biomass/coal steam co-gasification integrated with in-suit $\mathrm{CO}_{2}$ capture. Energy 2015; 83: 326-336.

[9]. Mostafavi E, Mahipey N, Manovic V. Anovel development of mixed catalyst-sorbent pellets for steam gasification of coal chars with in suit $\mathrm{CO}_{2}$ capture. Catalysis Today 2014; 237: 111-117.

[10]. Ma GY, Cai JJ, Zeng WW, Dong H. Analytical research on waste heat recovery and utilization of China's iron \& steel industry. Energy Procedia 2012; 14 : 1022-1028.

[11]. Cahyono RB, Ronzhan AN, Yasuda N, Nomura T, Hosokai S, Kashiwaya Y, Akiyama T. Integrated coal-pyrolysis tar reforming using steelmaking slag for carbon composite and hydrogen production. Fuel 2013; 109: 439-444.

[12]. Duan WJ, Yu QB, Wang K, Qin Q, Hou LM, Yao X, Wu TW. ASPEN Plus simulation of coal integrated gasification combined blast furnace slag waste heat recovery system. Energy Conversion and Management 2015; 100: 30-36.

[13]. $\mathrm{Xu} \mathrm{B}$, Lin BQ. Assessing $\mathrm{CO}_{2}$ emissions in China's iron and steel industry: A dynamic vector autoregression model. Applied Energy 2016; 161: 375-386.

[14]. Ishida M. Thermodynamic Made Comprehensible (New York: Nova Science 
Publishers Inc., 2002).

377 [15]. Akiyama T, Oikawa K, Shimada T, Kasai E, Yagi JI. Thermodynamic analysis of 378 thermochemical recovery of high temperature wastes. ISIJ International 2000; 40, 286-291.

380

381

382

383

384

385

386

387

388

389

390

391

392

393

394

395

396

397

[16]. Duan WJ, Li P, Lei W, Chen W, Yu QB, Wang K, Qin Q. Thermodynamic analysis of blast furnace slag waste heat-recovery system integrated with coal gasification. JOM 2015; 67(5): 1079-1085.

[17]. Duan WJ, Yu QB, Xie HQ, Qin Q, Zuo ZL. Thermodynamic analysis of hydrogen-rich gas generation from coal/steam gasification using blast furnace slag as heat carrier. International Journal of Hydrogen Energy 2014; 39: 11611-11619.

[18]. Luo SY, Zhou YM, Yi CJ. Hydrogen-rich gas production from biomass catalytic gasification using hot blast furnace slag as heat carrier and catalyst in moving-bed reactor. International Journal of Hydrogen Energy 2012; 37: 15081-15085.

[19]. Zhao LM, Wang H, Qing S, Liu HL. Characteristics of gaseous product from municipal solid waste gasification with hot blast furnace slag. Journal of Natural Gas Chemistry 2010; 19: 403-408.

[20]. Sun YQ, Zhang ZT, Seetharaman S, Liu LL, Wang XD. Characteristics of low temperature biomass gasification and syngas release behavior using hot slag. RSC Advances 2014; 4: 62105-62114.

[21]. Li P, Yu QB, Qin Q, Liu HX. Adaptability of coal gasification in molten blast furnace slag on coal samples and granularities. Energy \& Fuels 2011; 25: 
399

400

401

402

403

404

405

406

407

408

409

410

411

412

413

414

415

416

417

[22]. Tursun Y, Liu JG, Xu SP, Wei LG, Zuo WJ. Catalytic steam gasification of lignite olivine as solid heat carrier. Fuel 2013; 112: 641-645.

[23]. Jin H, Lu YJ, Liao B, Guo LJ, Zhang XM. Hydrogen production by coal gasification in supercritical water with a fluidized bed reactor. International Journal of Hydrogen Energy 2010; 35: 7151-7160.

[24]. Shabbar S, Janajreh I. Thermodynamic equilibrium analysis of coal gasification using Gibbs energy minimization method. Energy Conversion and Management $2013 ; 65: 755-763$.

[25]. Majumder AK, Jain R, Banerjee P, Barnwal JP. Development analysis of a new proximate analysis based correlation to predict calorific value of coal. Fuel 2008; 87(13-14): 3077-3081.

[26]. Noureddini H, Zhu D. Kinetics of transesterification of soybean oil. Journal of the American Oil Chemists Society 1997; 74(11): 1457-1463.

[27]. Maneerung T, Kawi S, Wang Chi-Hwa. Biomass gasification bottom ash as a source of $\mathrm{CaO}$ catalyst for biodiesel production via transesterification of palm oil. Energy Conversion and Management 2015; 92: 234-243.

[28]. Liu JX, Yu QB, Guo Q. Experimental investigation of liquid disintegration by rotary cups. Chemical Engineering Science 2012; 73: 44-50.

[29]. Liu JX, Yu QB, Li P, Du WY. Cold experiments on ligament formation for blast furnace slag granulation. Applied Thermal Engineering 2012; 40: 351-357.

[30]. Liu JX, Yu QB, Duan WJ, Qin Q. Experimental investigation on ligament 

888-893.

422 
424 Table 1 The proximate and elemental analysis of the coal

425 Table 2 The operating conditions in the gasification system

426 Table 3 Gasification performance of FS coal under different operating temperatures

$427 \quad(\mathrm{~S} / \mathrm{C}$ ratio $=2.0)$

428 Table 4 Gasification performance of FS coal under different S/C ratios (Temperature

$\left.429=1350^{\circ} \mathrm{C}\right)$

430 Table 5 Gasification performance of different types of coal (Temperature $=1350^{\circ} \mathrm{C}$

431 and $\mathrm{S} / \mathrm{C}$ ratio $=2.0)$

432 
434 Fig. 1 The schematic diagram of the experimental apparatus

435 Fig. 2 The schematic diagram of the primary reactor

436 Fig. 3 The effect of temperature on syngas fraction distribution of FS coal gasification

$437 \quad(\mathrm{~S} / \mathrm{C}$ ratio $=2.0)$

438 Fig. 4 The characteristic of $\mathrm{CE}, \mathrm{CGE}, \mathrm{YH}_{2}$ with different temperatures

439 Fig. 5 The effect of temperature on the viscosity of BFS in the FS coal gasification 440 system

441 Fig. 6 The effect of S/C ratio on syngas fraction distribution of FS coal gasification

$442 \quad\left(\right.$ Temperature $\left.=1350^{\circ} \mathrm{C}\right)$

443 Fig. 7 The characteristic of $\mathrm{CE}, \mathrm{CGE}, \mathrm{YH}_{2}$ with different $\mathrm{S} / \mathrm{C}$ ratios

444 Fig. 8 The effect of coal type on syngas fraction distribution (Temperature $=1350^{\circ} \mathrm{C}$

445 and $\mathrm{S} / \mathrm{C}$ ratio $=2.0$ )

446 Fig. 9 The characteristic of $\mathrm{CE}, \mathrm{CGE}$ and $\mathrm{YH}_{2}$ with different types of coal 447 (Temperature $=1350^{\circ} \mathrm{C}$, and $\left.\mathrm{S} / \mathrm{C}=2.0\right)$ 